O. Novak, Cand. Sc. (Pedag.), orcid.org/0000-0003-3187-1872, L. Levchenko, Cand. Sc. (Philos.), Assoc. Prof., orcid.org/0000-0002-9919-9018,

I. Levchenko, Dr. Sc. (Histor.), Assoc. Prof., orcid.org/0000-0001-9652-8755,

O. Kostenko, Cand. Sc. (Histor.), Assoc. Prof., orcid.org/0000-0003-0831-9158
Pereiaslav-Khmelnytskyi Hryhorii Skovoroda State Pedagogical University, Pereiaslav-Khmelnytskyi, Ukraine, e-mail: novakolyia@gmail.com

\title{
FEATURES OF MASTER'S DEGREE PROGRAMS IN UKRAINE: FORMATION OF ADMINISTRATIVE COMPETENCIES
}

Purpose. To examine the relevance of master's programs in higher education institutions of the USA, the European Union and Ukraine. Taking the example of administrative competencies formation in the Master of Education programs, to compare the relevance of majors and competencies for the Master of Education degree in the USA, Europe and Ukraine. Based on the results achieved, to recommend the sequence of modernization of master's programs in Ukraine in accordance with the standards of the European Higher Education Area.

Methodology. The authors used the comparative analysis method, which made it possible to compare the features of administrative competencies formation in master's programs in the United States, the European Union and Ukraine. The logical method of scientific knowledge allowed the authors to draw conclusions that justify the need for further modernization of master's programs in Ukraine in accordance with standards of the European Higher Education Area.

Findings. The authors have examined comparison of meanings, which are embedded in the phrase "administrative competences" in Ukraine, the USA and states of the European Union. The authors have concluded that in the Ukrainian educational system understanding of administrative competencies and need for their formation in university graduates differs little from their understanding in the USA and the European Higher Education Area. In examining master's degree programs in the USA and the State of the European Union, the authors have found that education is differentiated not only between states, as well as within states. The authors have concluded that modernization of the Ukrainian educational system in accordance with the standards of the European Higher Education Area does not threaten Ukrainian identity, and, instead, develops it. By comparing administrative competencies formation in the Master of Education programs in higher education institutions of the USA, Europe and Ukraine, the authors have found significant differences between these programs. The authors have developed recommendations for modernization of the Master of Education programs in accordance with the standards of the European Association for Quality Assurance in Higher Education.

Originality. The authors have proved the irrelevance of majors and competencies for the Master of Education degree in Ukraine in comparison with the USA and the States of the European Union. Taking the example of administrative competencies formation in the Master of Education programs in the higher education institutions of the USA, Europe and Ukraine, the authors have found that 1) in Ukraine master's programs are not divided into "research" and "professional", as is adopted in the USA and the states of the European Union; 2) the Master of Education programs in Ukraine provide mastering of majors which do not correspond to the classification adopted in the European Higher Education Area. The authors have recommended modernizing the Master of Education program in Ukraine in accordance with the standards of the European Association for Quality Assurance in Higher Education. Namely: 1) to divide master's programs into research and professional; 2) to standardize the Master of Education programs, and retain the following majors: curriculum and instruction; counseling; school psychology; administration.

Practical value. The research ensures consistency of modernization of master's programs in Ukraine in accordance with the standards of the European Higher Education Area. The results of the research can be used for administrative competencies formation in the Master of Education programs in accordance with the standards of the European Association for Quality Assurance in Higher Education.

Keywords: administrative competencies, master's programs, Master of Education, professional master's degrees

Introduction. Having signed the Bologna Declaration in 2005, Ukraine assumed obligations to reform the state educational system in accordance with the European standards. The main purpose of the Joint Declaration of the European Ministers of Education was to create the European Higher Education Area, in which un-

(C) Novak O., Levchenko L., Levchenko I., Kostenko O., 2019 dergraduate and graduate students could freely move, study and acquire the relevant competencies and diplomas in the universities of Europe.

In May 2005, at the Bergen Conference a three-cycle structure of higher education was introduced: Bachelor, Master, and Doctor. The States, who have signed the Bologna Declaration, assumed obligations to modernize higher education in accordance with qualifications 
adopted in Bergen [1]. In the process of higher education modernization, introduction of the competencybased approach acquires particular relevance. The main purpose of the competency-based approach in education is to focus the educational process on the acquisition, formation and improvement of competencies and competence.

In this research, the authors will examine formation of administrative competencies in the Master of Education programs in higher education institutions of the USA, the European Union and Ukraine. The main purpose of the article is:

1. To determine how administrative competencies formation in the Master of Education programs in Ukraine corresponds to similar programs in the USA and the states of the European Union.

2. To develop recommendation for master's programs modernization in Ukraine in accordance with the standards of the European Higher Education Area.

Presentation of the main research. Let us examine the comparison of meanings, which are embedded in the phrase "administrative competencies" in Ukraine, the USA and the States of the European Union. As a synonym for the term "administrative competencies", in Western literature the phrase "management of the job" is used. For the most part, in administrative competencies three main areas of research are distinguished:

1. The ability to organize one's time and set priorities of work.

2. The ability to define purposes and ways to achieve them.

3. The ability to plan one's working day and schedule work time.

The comparative analysis of administrative competencies, as well as wealth of meaning and practice that are associated with "management of the job", is considered in the research of N. Aleksandrova [2], V. Dodonova [3], O. Gaievska [4], A. Kyrychok [5], L. Ryabovol [6], and others. As a minimum, administrative competencies formation ensures:

1. Sustainable and predicted development of society (for example, A. Ursul's research [7]).

2. Development and dominance of a true political force in society, which provides effective state administration [8].

3. Integration of peoples and nations into a global society [9].

4. Personnel policy in all areas of activity, including state administration [10].

5. Solidarity between generations; preservation of individual, family, national and cultural traditions [11].

The urgency, opportunities and need for formation of administrative competencies in university graduates, are completely revealed in the research studies which deal with the problem of national identity in the face of the threats posed by globalization. For example, in the article "National Identity as an Important Topic of the Research of the Man in the Future", the administrative competencies opportunities for preserving the cultural identity of the young generation in the face of the threats posed by globalization of society are considered [12].
Based on the discussion of Fichte's concept of building national identity, Z. Kieliszek concludes that Fichte's ideas remain relevant, as they are part of the recommendations that help young generations to set priorities for actions and overcome the threats posed by globalization [12].

In general, comparing the meanings, which are embedded in the phrase "administrative competencies" in Ukraine, in the USA and the states of the European Union, the authors state their relevance. In the Ukrainian educational system understanding and need for formation of administrative competencies in university graduates, is not that different from their understanding in the USA and in the European Higher Education Area.

However, relevance in understanding of administrative competencies and need for their formation, does not exclude the difference in the approaches to their formation in university students. For example, Y. Lavrysh [13] and S. Rudenko [14] in their research indicate the difference between master's programs in Ukraine and in the states of Europe, and offer their own variants of modernization of the Ukrainian educational system in accordance with European Standards in Education. The authors support the conclusions reached by Y.Lavrysh and S. Rudenko. Adaptation of the Ukrainian education to European Standards meets current needs of Ukrainian society, which has made the choice for European integration. O. Bazaluk in his research underlines the importance of the reforms in the educational system. On the one hand, education develops the main features of the personality, including stereotypes of aggression and peacefulness [15]; on the other hand, education concentrates information, technological, and cultural capacities of society in the new generations [16].

Each society has its history of building institutes of State power, of education, as well as development of individual cultural practices. O. Pavlova, in the article "Politically-Technological Potential of Cultural Practices in Ukrainian Perspective", concludes that globalization processes do not suppress the national and cultural features of the society development; they rather open up new perspectives of development. Pavlova has proved that new information and communication technologies do not deny previous cultural practices; they rather aggravate them [17].

The analysis of master's programs in the USA and the States of the European Union show that, in spite of mobilized fear of globalization processes, and perhaps, despite these fears, education is differentiated not only between states, as well as within states. Based on the results of our own research, the authors have come to the following conclusion: modernization of the Ukrainian educational system to the European Higher Education Area Standards does not bear any threats to Ukrainian identity; it rather develops it. There is no risk of losing cultural identity in conditions of free migration within the European Community.

Let us consider formation of administrative competencies in the Master of Education programs in higher education institutions of the USA, the European Union and Ukraine. 
$\boldsymbol{U S A}$. In the USA, there are no general standards and requirements for administrative competencies formation in education. The website home page of the U.S. Department of Education contains such a warning: "Please note that in the U.S., the federal role in education is limited. Because of the Tenth Amendment, most education policy is decided at the state and local levels. So, if you have a question about a policy or issue, you may want to check with the relevant organization in your state or school district" [18].

Each state has its own laws and, accordingly, the requirements for education administrators and competencies, which they should possess. Certification of education administrators is carried out as of special education administrators. Moreover, about half of all states require separate certified competencies for administrators of special education and general education. That is, certification of administrators of preschool, school, and higher education is different. Certification of administrative competencies is carried out by state executive authorities, and not by federal (state) administration bodies.

Master's programs, which form administrative competencies in education, differ in the same variety. It should be noted that a master's degree, as an academic degree, is awarded not only by the universities, but by colleges as well as. The United States Department of Education classifies master's degree as research or professional ones. Moreover, formation of administrative competencies of the Master of Education can be carried out both in research, and professional master's program. Differences between the programs are significant. The main difference is that formation of administrative competencies in research master's program takes place at special courses, after which exams are taken. Professional master's degrees are obtained as a result of research in a specialized area. Their result is an approved project for the thesis.

We note that administrative competencies in education are formed not only in the Master of Education degrees program. For example, the Master of Cross-Cultural and International Education degree is awarded by Bowling Green State University, Bowling Green, Ohio. The program includes using of administrative competencies and leadership qualities for international educational projects, as well as for formation of international education partnerships.

The Association for Educational Communications and Technology awards the Master's degree in "Educational Technology". In each state, there is at least one university that has this master's program. The program includes formation of competencies of curriculum development, technology integration, Educational Technology policy counselling, and conducting relevant research for schools, colleges, and universities [19].

However, formation of administrative competencies is carried out mainly in the programs of "The Master of Science in Leadership" and "Master of Business Administration" (MBA). These very master's programs put emphasis on formation of competencies of leaderfollower, coaching, team development, project leadership, and behavioral motivation theories.
In the vast majority of states, the Master of Education degree is not enough to get administrative position in a college or university. The certificate testifying the area of research in the field of educational administration is required. As a minimum, school administrator licensure and master's degree in educational administration are required to administer a college and university.

Europe. There exists a great variety of master's programs in the states of the European Union. The Bologna Declaration, signed in 1999, was intended just for standardization and creation of the European Higher Education Area.

In 2004 the European Association for Quality Assurance in Higher Education (ENQA) was established, which, is engaged, inter alia, in master's programs quality monitoring in the process of their standardization in accordance with the standards of the European Higher Education Area.

Over the past 20 years, much has been achieved. However, the Master of Education programs remain varied. In the states of the European Union, the following majors can be acquired in the Master of Education programs:

1. Curriculum and instruction, which allows teaching at schools.

2. Counsellor education, which allows working as mental health professionals and provides access to obtaining a state licensure for this major.

3. School counselling, which allows working as a school counsellor.

4. Academic enrichment, which improves the qualifications of the teacher in specific subjects, as well as allows the teacher to change the research area to a more demanding one in the market.

5. Higher education and student affairs. This major allows holding administrative positions in colleges and universities, relating to the work with students.

6. Adult education.

7. Special education, which allows working with students with autism, with intellectual disabilities, and others.

8. Religious education.

9. Media and technology.

In the majority of states throughout the world the Master of Education (M.Ed. or Ed.M.), or the Master of Arts in Education (M.A.Ed. or M.A.E.), or the Master of Science in Education (M.S.Ed. or M.S.E.) programs, are standardized. Regardless of the title, they are divided into the following majors: curriculum and instruction; counseling; school psychology; and administration.

Ukraine. The main feature of administrative competencies formation in master's degree programs in Ukraine is their obligatoriness for teachers, researchers and administrators. If in the USA and in the states of the European Union master's programs for teachers', researchers', and education administrators' training are different, there is no such division in Ukraine. Therefore, all the Master of Education degree programs in Ukraine include mastering teaching, research and administration skills. 
Let us take the example of the master's program of "Instruction in Higher Education". In Ukraine, instruction in higher education is one of the areas of pedagogy. This is the science of upbringing, instruction and education of youth and adults. In Ukraine master's programs are not divided into "research" and "professional", as adopted in the USA and in the states of the European Union. Hence, the "Instruction in Higher Education" program includes scientific and professional training, according to the requirements of the Ministry of Education of Ukraine.

The Master's program of "Instruction in Higher Education" includes formation of the following competencies: basic understanding of psychology and pedagogy fundamentals that promote general culture formation and personality socialization, propensity for ethical values, understanding of causal relationships of society development, and globalization processes; ability to evaluate critically and foresee political, economic, cultural, and other events and phenomena in accordance with the relevant volume of knowledge; ability to communicate effectively, in particular, by means of information technology; ability to plan and implement certain measures in socio-economic systems administration; ability to organize teamwork; business communication abilities in the professional sphere, knowledge of the fundamentals of business communication, teamwork skills; ability to conduct a discussion on general economic matters and application-specific issues of economic system administration; ability to use modern information and Internet technologies for the researcher's inquiry, and others.

Besides, the Master of Education programs in Ukraine differ in majors. For example, only the state order on master's training in Pereyaslav-Khmelnytsky Hryhoriy Skovoroda State Pedagogical University includes the following educational and professional, and educational and scientific programs: Psychology, Social Work, Vocational Education (Commodity Research), Vocational Education (Service Sector), Vocational Education (Labor Protection), Vocational Education (Document Research), Secondary Education (Musical Art), Secondary Education (Ukrainian Language and Literature), Secondary Education (Language and Literature (specifying the language)), Elementary Education, Preschool Education, and so forth [20].

Conclusions. Thus, our research concludes that master's programs in Ukraine are substantially different from master's programs in the USA and the state of the European Union. Taking the example of administrative competencies formation in the Master of Education programs in the USA, Europe and Ukraine higher education institutions, we can state the following:

1. In Ukraine, master's programs are not divided into "research" and "professional" ones, as is adopted in the USA and the states of the European Union.

2. The Master of Education programs in Ukraine include research, professional and administrative training.

3. The Master of Education programs in Ukraine include mastering majors, which do not correspond to the qualification adopted within the European Higher Education Area.
In order to fulfil Ukraine's assumed commitments to integrate into the European Higher Education Area, it is necessary to modernize the Master of Education programs in Ukraine. The authors offer to use as the basis the standards of the European Association for Quality Assurance in Higher Education (ENQA), and, initially, to do the following:

Firstly, to divide master's programs into research and professional ones. This step is due not only to the need for further integration of the Ukrainian educational system into the European Higher Education Area; it is to identify the division into scientific, educational and administrative activities as well as. For, in essence, each of these activities requires a special kind of competencies and their certification at the state level. More indepth specialization of master's programs will ensure high quality of university graduate's training that meets the standards of the European Association for Quality Assurance in Higher Education (ENQA).

Secondly, the authors offer to standardize the Master of Education programs in accordance with the programs, adopted for the Master of Education in the European Union. The Master of Education degrees programs must be field-specific. As well as in the majority of the world's leading states, these programs should train professionals of a more in-depth level of training, than the Bachelor's level. The authors offer the following majors of M. Ed. programs: curriculum and instruction; counselling; school psychology; and administration. Consequently, administrative competencies formation in the Master of Education program will be carried out, mainly, in the Research Program Administration.

\section{References.}

1. Feeney, S. and Hogan, J., 2017. A Path Dependence Approach to Understanding Educational Policy Harmonisation: The Qualifications Framework in The European Higher Education Area. High Educ Policy, 30, pp. 279-298. DOI: 10.1057/s41307-016-0019-3.

2. Aleksandrova, N., 2016. Cross-Cultural Competence of Specialists Engaged in International Business, Economic Relationships and Management: Content and Structure (With a view to business challenges). Future Human Image [pdf], 3(6), pp. 1-15. Available at: <http://www.fhijournal.org/wp-content/uploads/ 2016/09/3-6-2016-01-Aleksandrova.pdf> [Accessed 23 September 2017].

3. Dodonova, V., 2014. The Postnonclassical Horizons of Social Management. Philosophy and Cosmology, 13, pp. 233-244.

4. Gaievska, O., 2015. Generally Civilized Context of Governing the Social Organization of the World. Philosophy and Cosmology, 15, pp. 182-197.

5. Kyrychok, A., 2017. The Main Determinants of Improvement of Model of Educational Training of Specialists in the Field of PR Based on Competency Approach. Future Human Image, 7, pp. 71-85.

6. Ryabovol, L., 2017. The Professional Training of Law and History Teachers as a Research Subject. Future Human Image, 8, pp. 140-148. 
7. Ursul, A. and Ursul, T., 2018. Environmental Education for Sustainable Development. Future Human Image, 9, pp. 115-125. DOI: 10.29202/fhi/9/12.

8. Svyrydenko, D. and Yatsenko, O., 2018. Dialectics of Nominal and Real Power in the Ukrainian and World Politics. Ukrainian Policymaker, 2, pp. 33-40. DOI: 10.29202/up/2/5.

9. Bazaluk, O., Svyrydenko, D. and Terepyshchyi, S., 2017. Structural-Functional Models of Integration and Reintegration of Ukrainian Educational Landscape. Naukovyi Visnyk Natsionalnoho Hirnychoho Universytetu, 5, pp. 163-168.

10. Naumenko, R., 2018. Philosophy of Public Governance: Manpower Policy of Modern Ukraine in the Context of Globalization. Philosophy and Cosmology, 20, pp. 106-112. DOI: 10.29202/phil-cosm/20/9.

11. Bazaluk, O., 2017. Plato's and Isocrates' Traditions in the Development of Educational Theories in the History of Culture. Annals of the University of Craiova Philosophy Series, 40(2), pp. 5-18.

12. Kieliszek, Z., 2018. National Identity as an Important Topic of the Research of the Man in the Future: "Opening" the Potential of the Fichtean Concept of National Identity. Philosophy and Cosmology, 20, pp. 83-91. DOI: 10.29202/phil-cosm/20/7.

13. Lavrysh, Y., 2018. Implementation of Transformative Sustainability Learning into Engineering Curricular. Future Human Image, 9, pp. 63-73. DOI: 10.29202/ fhi/ $9 / 6$.

14. Rudenko, S., Sapenko, R., Bazaluk, O. and Tytarenko, V., 2018. Management Features of International Educational Projects Between Universities of Poland and Ukraine. Naukovyi Visnyk Natsionalnoho Hirnychoho Universytetu, 2, pp. 142-147. DOI: 10.29202/nvn$\mathrm{gu} / 2018-2 / 21$.

15. Bazaluk, O., 2017. The Theory of War and Peace, Geophilosophy of Europe. Cambridge Scholars Publishing.

16. Bazaluk, O., 2018. The Feature Transformations of the Basic Meanings of Greek Paideia in the Educational Theories in the Middle Ages. Schole, 12.1, pp. 243-258. DOI: 10.21267/AQUILO.2018.12.10428.

17. Pavlova, O., 2018. Politically-Technological Potential of Cultural Practices in Ukrainian Perspective. Ukrainian Policymaker, 2, pp. 20-26. DOI: 10.29202/ up $/ 2 / 3$.

18. The U.S. Department of Education, 2018. Laws \& Guidance. Overview [online]. Available at: <https:// www2.ed.gov/policy/landing.jhtml? src $=$ pn $>$ [Accessed 11 July 2018].

19. Carnegie Mellon University, 2018. Masters of Educational Technology and Applied Learning Science (MET$A L S$ ) [online]. Available at: <https://metals.hcii.cmu. edu/> [Accessed 14 July 2018].

20. Pereiaslav-Khmelnytskyi Hryhorii Skovoroda State Pedagogical University, 2018. Supplementary to Protocol No. 3 of meeting of the competition committee of the Ministry of Education and Science of Ukraine [online]. Available at: <https://drive.google.com/file/d/ 10WSkYTI2LDDXFx97Tlk9OEO0oUJkziRl/view> [Accessed 20 September 2018].

\section{Особливості магістерських програм \\ в Україні: формування управлінських компетенцій}

\author{
О. М. Новак, Л. Ю. Левченко, І. М. Левченко, \\ О. О. Костенко
}

Переяслав-Хмельницький державний педагогічний університет імені Григорія Сковороди, м. Переяслав-Хмельницький, Україна, e-mail: novakolyia@gmail.com

Мета. Проаналізувати відповідність магістерських програм у вищих навчальних закладах США, Європейського Союзу та України. На прикладі формування управлінських компетенцій за програмами магістра освіти порівняти відповідність спеціальностей і компетенцій для ступеня магістра освіти у США, Європі та Україні. На засадах отриманих результатів рекомендувати послідовність модернізації магістерських програм в Україні до стандартів Європейського простору вищої освіти.

Методика. Автори використали метод компаративного аналізу, що дозволив порівняти особливості формування управлінських компетенцій у магістерських програмах США, Європейського Союзу та України. Логічний метод наукового пізнання дозволив авторам сформулювати висновки, що обгрунтовують необхідність подальшої модернізації магістерських програм в Україні під стандарти $\Theta_{\text {в- }}$ ропейського простору вищої освіти.

Результати. Автори розглянули відповідність змісту, що вкладається у словосполучення „управлінські компетенції“ в Україні, США та державах Європейського Союзу. Автори прийшли до висновку, що в освітній системі України розуміння управлінських компетенцій і необхідності їх формування у випускників вищих навчальних закладів, мало чим відрізняється від їх розуміння у США та Європейському просторі вищої освіти. Аналізуючи магістерські програми у США й державах Європейського Союзу, автори виявили, що підходи до освіти диференційовані не тільки між державами, але й усередині держав. Автори прийшли до висновку, що модернізація української освітньої системи під стандарти Європейського простору вищої освіти не несе загроз українській ідентичності, а навпаки ії розвиває. Порівнявши формування управлінських компетенцій за програмами магістра освіти у вищих навчальних закладах США, Європи та України автори виявили істотні відмінності цих програм. Автори розробили рекомендації для модернізації програм магістра освіти відповідно до стандартів Європейської асоціації із забезпечення якості вищої освіти.

Наукова новизна. Автори довели невідповідність спеціальностей і компетенцій для ступеня магістра освіти в Україні в порівнянні із США та країнами Європейського Союзу. На прикладі формування управлінських компетенцій за програмами магістра освіти у вищих навчальних закладах США, Європи та України автори встановили, що: 1) в Україні магістерські програми не поділяють на „дослідницькі“ та „професійні““, як прийнято у США та державах 
Європейського Союзу; 2) програми магістра освіти в Україні передбачають оволодіння спеціальностями, що не відповідають класифікації, прийнятій в Европейському просторі вищої освіти. Автори рекомендували модернізувати програму магістра освіти в Україні відповідно до стандартів Европейської асоціації із забезпечення якості вищої освіти. А саме: 1) розділити магістерські програми на „дослідницькі““ та „професійні“; 2) уніфікувати програми магістра освіти, залишити такі спеціальності: навчальні програми й педагогіка (curriculum and instruction); консультування (counseling); шкільна психологія (school psychology); адміністрування (administration).

Практична значимість. Проведене дослідження забезпечує послідовність модернізації магістерських програм в Україні до стандартів Свропейського простору вищої освіти. Отримані під час дослідження результати можуть використовуватися для формування управлінських компетенцій за програмами магістра освіти за стандартами Європейської асоціації із забезпечення якості вищої освіти.

Ключові слова: інститут права власності, економічна безпека, економічний аналіз права, економічна теорія права власності

\section{Особенности магистерских программ в Украине: формирование управленческих компетенций}

\section{О. М. Новак, Л. Ю. Левченко, И. Н. Левченко, О. А. Костенко}

Переяслав-Хмельницкий государственный педагогический университет, г. Переяслав-Хмельницкий, Украина, e-mail: novakolyia@gmail.com

Цель. Проанализировать соответствие магистерских программ в высших учебных заведениях США, Европейского Союза и Украины. На примере формирования управленческих компетенций по программам магистра образования сравнить соответствие специальностей и компетенций для степени магистра образования в США, Европе и Украине. На основе полученных результатов рекомендовать последовательность модернизации магистерских программ в Украине к стандартам Европейского пространства высшего образования.

Методика. Авторы использовали метод компаративного анализа, который позволил сравнить особенности формирования управленческих компетенций в магистерских программах США, Европейского Союза и Украины. Логический метод научного познания позволил авторам сформулировать выводы, которые обосновывают необходимость дальнейшей модернизации магистерских программ в Украине под стандарты Европейского пространства высшего образования.

Результаты. Авторы рассмотрели соответствие смыслов, которые вкладываются в словосочетание „Управленческие компетенции“ в Украине, США и государствах Европейского Союза. Авторы пришли к выводу, что в образовательной системе Украины понимание управленческих компетенций и необходи- мости их формирования у выпускников высших учебных заведений, мало чем отличается от их понимания в США и Европейском пространстве высшего образования. Анализируя магистерские программы в США и государствах Европейского Союза, авторы обнаружили, что образование дифференцировано не только между государствами, но и внутри государств. Авторы пришли к выводу, что модернизация украинской образовательной системы под стандарты Европейского пространства высшего образования не несет угроз украинской идентичности, а наоборот её развивает. Сравнив формирование управленческих компетенций по программам магистра образования в высших учебных заведениях США, Европы и Украины авторы обнаружили существенные отличия этих программ. Авторы разработали рекомендации для модернизации программ магистра образования в соответствии со стандартами Европейской ассоциации по обеспечению качества в высшем образовании.

Научная новизна. Авторы доказали несоответствие специальностей и компетенций для степени магистра образования в Украине в сравнении с США и государствами Европейского Союза. На примере формирования управленческих компетенций по программам магистра образования в высших учебных заведениях США, Европы и Украины авторы установили, что: 1) в Украине магистерские программы не делят на „исследовательские“ и „профессиональные“, как принято в США и государствах Европейского Союза; 2) программы магистра образования в Украине предусматривают овладение специальностями, которые не соответствуют классификации, принятой в Европейском пространстве высшего образования. Авторы рекомендовали модернизировать программу магистра образования в Украине в соответствии стандартам Европейской ассоциации по обеспечению качества в высшем образовании. А именно: 1) разделить магистерские программы на „исследовательские“ и „профессиональные“; 2) унифицировать программы магистра образования, оставить следующие специальности: учебные программы и педагогика (curriculum and instruction); консультирование (counseling); школьная психология (school psychology); администрирование (administration).

Практическая значимость. Проведенное исследование обеспечивает последовательность модернизации магистерских программ в Украине к стандартам Европейского пространства высшего образования. Полученные в ходе исследования результаты могут использоваться для формирования управленческих компетенций по программам магистра образования по стандартам Европейской ассоциации по обеспечению качества в высшем образовании.

Ключевые слова: управленческие компетенции, магистерские программы, магистр образования, исследовательские магистерские программы, профессиональные магистерские программы

Рекомендовано до публікації докт. філос. наук Д.Б. Свириденком. Дата надходження рукопису 14.01.18. 